(hopefully, though not necessarily, with a band pattern like that found in normal chromosomes). Progress in these experiments will be reported in due course.

${ }^{2}$ Schmitt, F. O.. Gross, J., and Highberger, J. H., Symp. Soc. Exp. Biol, $9,148(1955)$

2 Schmitt, F. O., Gross, J., and Highberger, J. II., Exp. Cell Res. $326(1955)$

${ }^{3}$ Boedtker, H., and Doty, P., J. Amer. Chem. Soc., 77, 248 (1955).

- Ramachandran, G. N., and Kartha, G., Nature, 176, 593 (1955).

${ }^{5}$ Ramachandran, G. N., and Kartha, G., Proc. Indian Acad. Sci., 42, 215 (1955)

6 Rich, A., and Crick, F. H. C., Nature, 176, 915 (1955).
${ }^{7}$ Cowan, P. M., McGavin, S., and North, A. C. T., Nature, 176, 1062 (1955).

${ }^{8}$ Bear, R. S., "Adv. Protein Chem.", 7, 69 (1952).

${ }^{8}$ Hodge, A. J., Proc. U.S. Nat. Acad. Sci., 38, 850 (1952).

${ }^{10}$ Locker, R., and Schmitt, F. O. (unpublished).

${ }^{11}$ Davison, P. F., Conway, B. F., and Butler, J. A. V., "Progress in Biophysics", 4, 148 (1954).

${ }^{12}$ Allfrey, V. G., Mirsky, A. E., and Stern, H., “Adv. Enzymol.”, 16, 411 (1955).

${ }^{13}$ Reichmann, M. E., Rice, S. A., Thomas, C. A., and Doty, P., J. Amer. Chem. Soc., 76, 3047 (1954).

${ }^{14}$ Doty, P., Proceedings Third International Congress of Biochemistry, Brusseis, 1955 (in the press).

${ }^{15}$ Goldschmidt, R. B., "Theoretical Genetics" (Univ. Calif. Press, 1955).

\title{
OBITUARIES
}

\section{Prof. Émile Borel}

THE rapid progress of mathematical analysis in the early years of the present century was due in considerable measure to the influence of the great French school, of which Emile Borel, whose death occurred on February 3 at the age of eighty-four, was a leading figure. To high creative ability, he added expository skill and unusual powers of organization; his name is known throughout the mathematical world not only for the doctrines to which it is attached - the Heine-Borel theorem, the Borel summation process, Borel sets-but also for the vast co-operative enterprises which he directed.

The theory of sets was more warmly welcomed in France, so Cantor thought, than in its German home; certainly the volumes of Jordan's classic "Cours d'Analyse" suggested that irksome continuity restrictions could only be removed by some method more powerful than that author's theory of content. In 1898, Borel's "Leçons sur la théorie des fonctions" provided a new theory of measure, while Baire's thesis on discontinuous functions appeared in the same year; and thus the way was open for the remarkable advances of the next decade. The booklet of 1898, based on lectures given at the Ecole Normale, was followed by similar volumes-on divergent series, integral functions, meromorphic functionsall of great value to the students of analysis. The success of the series caused its scope to be broadened, and other writers contributed, under Borel's direction, notably Baire, Lindelöf and Lebesgue. The latter's two brilliant tracts, on integration and on trigonometrical series, showed for the first time to a wide public the full precision and power of the new theory of measure and of the new integral of Lebesgue. Borel never lost interest in the series of monographs ; he constantly revised his own earlier volumes and prepared new ones, the latest appearing in 1952 . 'This bore on the constructive definition and effective calculation of numbers, a topic on which he had always held strong views-strong enough at one time to carry him into a heated controversy with Lebesgue. To-day a mathematical library without the Borel monographs is unthinkable.

Shortly after the First World War, Borel, whose chair in the Faculty of Sciences at Paris was that of probability and mathematical physics, undertook the direction of another large co-operative enterprise, the famous "Traité du calcul des probabilités", in four volumes, each of five or six parts; and this itself was supplemented by a further series of monographs on probability, one of which was Borel's own work on the mathematical theory of bridge.
Borel's considerable powers of exposition were not confined to these two famous undertakings; his writings range from school geometry to relativity, all with a sureness of touch and an almost deceptive ease of manner. His triple claim to high rank in the hierarchy of mathematicians, as creative thinker, illuminating writer and powerful organizer, will cause his name long to be remembered.

T. A. A. Broadbent

\section{Dr. W. L. H. Duckworth}

THE death, on February 14, of Dr. W. L. H. Duckworth, at the age of eighty-five, has removed from the Cambridge scene a scholar and a teacher of great distinction. Born in Liverpool in 1870, he was educated in Birkenhead and in France before going to Jesus College, Cambridge, in 1889. His associations with this College, of which he was elected a Fellow in 1893, were to be most intimate for the remainder of his long life, and culminated in his olection to the mastership in 1940. At the age of seventy-five he retired from the mastership but continued to live in Jesus College until his final illness. He was president of the Anatomical Society during 1943-45.

Duckworth had very wide interests in anatomy, teratology, primatology, anthropology, archæology and general natural history. He commenced work in the Anatomy School under Alexander Macalister shortly after obtaining a double first in the Natural Sciences Tripos. This connexion with anatomy he maintained during his clinical studies at St. Bartholomew's Hospital, London, and in 1899 a University lectureship in Cambridge in physical anthropology was established for him. In 1919 he was elected to a readership in human anatomy-a post which he held until 1940. After his retirement he maintained his interest in the collections in the Anatomy School and, in spite of physical disability, did some College and University teaching well into his ninth decade. In his maturity Duckworth's formal teaching was most impressive; complete command of the facts, great blackboard artistry, an almost pedantic accuracy in description ("it is not so much a whorl as a convolution") and an eighteenth-century aristocratic manner combined to give a character to his lectures which was much appreciated by students of all levels of ability and assiduity.

During the early years of the century, Duckworth travelled widely on archæological and anthropological expeditions, and on visits to departments of anatomy on the Continent. At the same time he pursued the study of human skulls and of recent primates with a 